\title{
Sesquiterpene Coumarins from Ferula sinkiangensis Act as Neuroinflammation Inhibitors
}

\author{
Authors \\ Yachao Xing ${ }^{1,2}$, Ning $\mathrm{Li}^{1,3}$, Di Zhou ${ }^{1}$, Gang Chen ${ }^{1,3}$, Kun Jiao ${ }^{4}$, Wenli \\ Wang ${ }^{1}$, Yingying $\mathrm{Si}^{1}$, Yue $\mathrm{Hou}^{4}$ \\ Affiliations \\ 1 School of Traditional Chinese Materia Medica 49\#, Shenyang \\ Pharmaceutical University, Shenyang, China \\ 2 Shanghai Haini Pharmaceutical Co. Ltd., Yangtze River Pharma- \\ ceutical Group, Shanghai, China \\ 3 Key Laboratory of Structure-Based Drug Design and Discovery, \\ Shenyang Pharmaceutical University, Ministry of Education, \\ Shenyang, China \\ 4 College of Life and Health Sciences, Northeastern University, \\ Shenyang, China \\ Key words \\ Awei, resin of Ferula sinkiangensis, Umbelliferae, sesquiterpene \\ coumarins, neuro-inflammation, Alzheimer's disease \\ $\begin{array}{ll}\text { received } & \text { Dec. 10, } 2015 \\ \text { revised } & \text { May 13, } 2016 \\ \text { accepted } & \text { May } 18,2016\end{array}$ \\ Bibliography \\ DOI http://dx.doi.org/10.1055/s-0042-109271 \\ Published online July 15, 2016 | Planta Med 2017; 83: 135-142 \\ (c) Georg Thieme Verlag KG Stuttgart · New York I ISSN 0032-0943 \\ Correspondence \\ Dr. Ning Li \\ School of Traditional Chinese Materia Medica 49\#, Key Laboratory of \\ Structure-Based Drug Design and Discovery, Shenyang Pharmaceutical \\ University, Ministry of Education \\ Wenhua Road 103, Shenyang 110016, China \\ Tel.: + 862423986475 , Fax: + 862431509368 \\ liningsypharm@163.com
}

\author{
Correspondence \\ Dr. Yue Hou \\ College of Life and Health Sciences, Northeastern University \\ Wenhua Road 3-11, Shenyang 110004, China \\ Tel.: + 862483656116 , Fax: + 862483656116 \\ houyue@mail.neu.edu.cn \\ Aupporting information available online at \\ http://www.thieme-connect.de/products
}

\begin{abstract}
Neuroinflammation mediated by microglia cells plays a critical role in the development of Alzheimer's disease. To identify novel natural neuroinflammation inhibitors, a bioactivity-guided phytochemical research was performed on the traditional Chinese medicine "Awei", that exhibited a significant inhibitory effect on nitric oxide production in over-activated microglia cells. The research identified sixteen bioactive sesquiterpene coumarins (two new and fourteen known ones) in the effective extract of Ferula sinkiangensis. Further, the anti-neuroinflammatory activities in BV-2 microglial cells were evaluated by monitoring LPS-induced nitric oxide production. In conclusion, the major constituent, ( $\left.3^{\prime} S, 5^{\prime} S, 8^{\prime} R, 9^{\prime} S, 10^{\prime} R\right)$-kellerin $(1.5 \%$, w/w), should be responsible for the anti-neuroinflammatory effect exhibited by Awei. Furthermore, it might be a potential natural therapeutic agent for Alzheimer's disease. The research indicated moreover, that its primary mechanism is the inhibition of mRNA expression of the inflammatory cytokines nitric oxide, tumor necrosis factor- $\alpha$, cyclooxygenase- 2 , interleukin-6 and interleukin-1 $\beta$.
\end{abstract}

\section{Introduction}

Alzheimer's disease (AD) is a complex neurodegenerative disease characterized by progressive cognitive impairments and severe irreversible behavioral abnormalities, and ultimately causes death [1]. AD affects more than 36 million people worldwide, mostly elderly adults, and is reportedly associated with plaques and tangles in the brain [2]. The cause and progression of AD are still not well understood. Although there is no known clinical treatment that can stop or reverse the progression of the disease completely, one approach is to investigate traditional herbals as possible natural therapeutic agents.
Excessive inflammatory responses in the central nervous system (CNS) play a critical role in the pathogenesis of AD [3-4]. Neuroinflammation is a key defense mechanism against infectious agents and neuronal injuries in the CNS. However, excessive or sustained neuroinflammatory processes may result in neuronal damage [5-6]. Microglial cells, the resident macrophage-like immune cells, produce various proinflammatory cytokines in response to inflammatory signals. Those cytokines include nitric oxide (NO), tumor necrosis factor $\alpha$ (TNF- $\alpha$ ), and interleukin $1 \beta$ (IL$1 \beta)$, which contribute to the progressive damage in $A D$ [7-8]. Thus, the anti-neuroinflammatory effect of inhibiting microglial over-activation may become a promising therapeutic target for AD. 
Bicyclic sesquiterpene coumarin
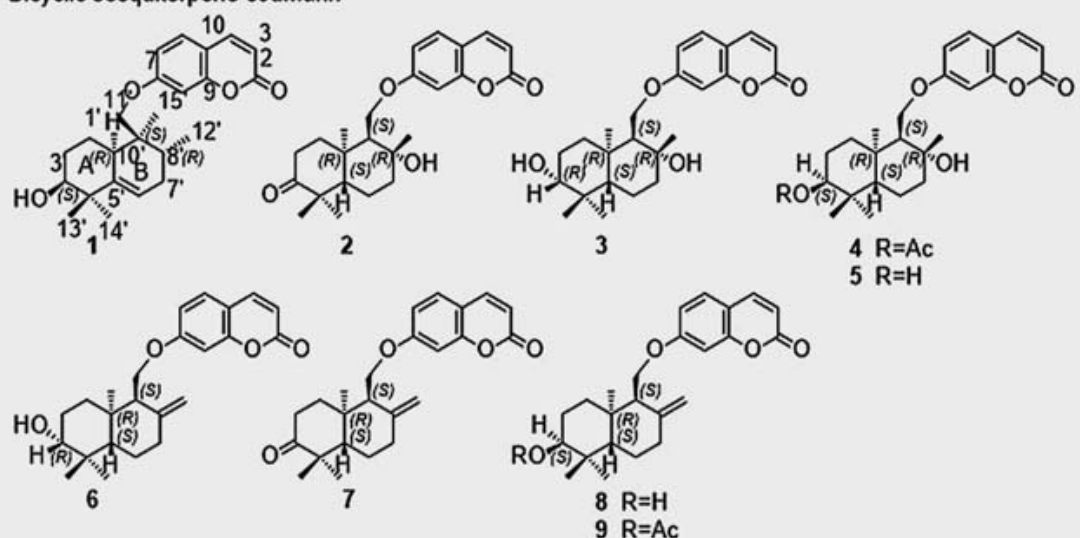

Monocyclic sesquiterpene coumarin

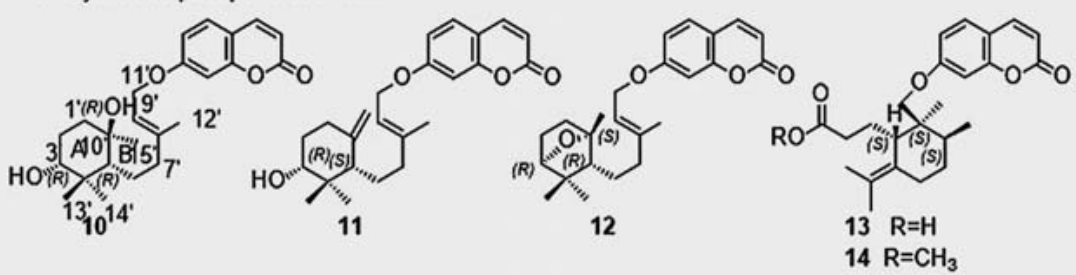

Acyclic sesquiterpene coumarin
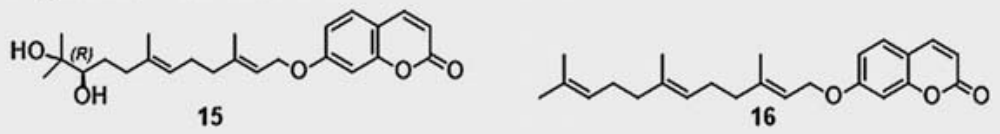

Fig. 1 The structure of isolated sesquiterpene coumarins.

Our previous studies screened 40 herbal medicines by means of anti-neuroinflammatory activity assays and phytochemical analysis [9-12]. One of the results was that the chloroform extract of Awei (the gum resin from Ferula sinkiangensis K. M.Shen) exhibits a significant effect.

The genus Ferula belongs to the family Umbelliferae, which is widely distributed throughout central Asia, especially in Iran. Several species of Ferula have been used as folk medicine. For example, the roots of Ferula persica Willd. var. persica Chamberlain have been used to treat diabetes [13], and Ferula asafoetida H.Karst. is known as a traditional medicine for the therapy of asthma, epilepsy, stomachache, flatulence, intestinal parasites, weak digestion and influenza [14]. In addition, Ferula fukanensis K. M. Shen is widely used for the treatment of rheumatoid arthritis and bronchitis [15].

The gum resin produced by plants of the Ferula genus is usually called "Awei" in China. The Awei from F. sinkiangensis and F. fukanensis are recognized in the Chinese Pharmacopoeia as Traditional Chinese Medicines. Phytochemical research has revealed that derivatives of sesquiterpene coumarins are responsible for diverse bioactivities exhibited by plants of the Ferula genus, including antitumor [16], anti-immune inflammatory [15, 17], antibacterial $[18,19]$, and disinsection $[20,21]$ activity. However, there are few reports of the genus Ferula with respect to a potential therapeutic effect on $A D$ by targeting the inhibition of over-activation of microglial cells.

Based on the previous results of screening, bioactivity-guided isolation and bioassay were performed with LPS-induced BV-2 cells and assessed by multiple chromatography and spectroscopy methods (1D and 2D NMR, MS, single-crystal X-ray analysis, and $E C D)$. We also investigated the primary mechanism of the major component and the brief structure and activity relationship (SAR) of the bioactive compounds.

\section{Results and Discussion}

The chloroform extract of $F$. sinkiangensis significantly inhibited the NO production in LPS-induced BV-2 microglial cells with an $I C_{50}$ value of $1.66 \pm 1.10 \mu \mathrm{g} / \mathrm{mL}$. Sixteen bioactive sesquiterpene coumarins ( $\triangleright$ Fig. 1 ) were isolated from the chloroform extract: $\left(3^{\prime} S, 8^{\prime} R, 9^{\prime} S, 10^{\prime} R\right)$-sinkianol A (1), (5'S, $\left.8^{\prime} R, 9^{\prime} S, 10^{\prime} R\right)$-ferukrinone (2), ferukrin (3), (3'S, $\left.5^{\prime} S, 8^{\prime} R, 9^{\prime} S, 10^{\prime} R\right)$-kellerin (4), (3'S, $5^{\prime}$ $S, 8^{\prime} R, 9^{\prime} S, 10^{\prime} R$ )-deacetylkellerin (5), farnesiferol $A(6)$, farnesiferone $A(7)$, gummosin (8), polyanthinin (9), $\left(3^{\prime} R, 5^{\prime} R, 10^{\prime} R\right)$-sinkianol B (10), farnesiferol B (11), farnesiferol C (12), galbanic acid (13), methyl galbanate (14), karatavicinol (15), and umbelliprenin (16). Further, these sixteen compounds were elucidated by means of spectral data analysis (1D and 2D NMR, MS, single-crystal X-ray 
- Table $1{ }^{1} \mathrm{H}-\mathrm{NMR}$ and ${ }^{13} \mathrm{C}-\mathrm{NMR}$ spectra data of compounds 1 and 10 measured in $\mathrm{CDCl}_{3}$.

\begin{tabular}{|c|c|c|c|c|}
\hline \multirow[t]{2}{*}{ Position } & \multicolumn{2}{|l|}{$1^{\mathrm{a}}$} & \multicolumn{2}{|l|}{$10^{\mathrm{b}}$} \\
\hline & $\delta_{\mathrm{H}}(/$ in $\mathrm{Hz})$ & $\delta c$ & $\delta_{\mathrm{H}}(\mathrm{in} \mathrm{Hz})$ & $\delta c$ \\
\hline $1^{\prime}$ & $1.98(1 \mathrm{H}, \mathrm{tdd}, 14.0,4.5,2.5, \mathrm{H}-\alpha) ; 1.76(1 \mathrm{H}, \mathrm{m}, \mathrm{H}-\beta)$ & 29.4 & $1.80(1 \mathrm{H}, \mathrm{m}, \mathrm{H}-\alpha) ; 1.46(1 \mathrm{H}, \mathrm{m}, \mathrm{H}-\beta)$ & 41.2 \\
\hline $2^{\prime}$ & $1.66(1 \mathrm{H}, \mathrm{m}, \mathrm{H}-\alpha) ; 1.48(1 \mathrm{H}, \mathrm{m}, \mathrm{H}-\beta)$ & 23.3 & $1.51(1 \mathrm{H}, \mathrm{m}, \mathrm{H}-\alpha) ; 1.76(1 \mathrm{H}, \mathrm{m}, \mathrm{H}-\beta)$ & 29.2 \\
\hline $3^{\prime}$ & $3.47(1 \mathrm{H}, \mathrm{s})$ & 76.7 & $3.32(1 \mathrm{H}, \mathrm{dd}, 11.0,4.0)$ & 78.4 \\
\hline $4^{\prime}$ & - & 42.3 & - & 40.6 \\
\hline $5^{\prime}$ & - & 142.6 & $1.13(1 \mathrm{H}, \mathrm{t}, 4.2)$ & 55.5 \\
\hline $6^{\prime}$ & $5.50(1 \mathrm{H}, \mathrm{brt}, 3.3)$ & 120.0 & $1.64(1 \mathrm{H}, \mathrm{m}, \mathrm{H}-\alpha) ; 1.50(1 \mathrm{H}, \mathrm{m}, \mathrm{H}-\beta)$ & 24.2 \\
\hline $7^{\prime}$ & $1.87(1 \mathrm{H}, \mathrm{m}, \mathrm{H}-\alpha) ; 2.21(1 \mathrm{H}, \mathrm{br} . \mathrm{d}, 17.8, \mathrm{H}-\beta)$ & 31.7 & $2.20(2 \mathrm{H}, \mathrm{m})$ & 42.7 \\
\hline $8^{\prime}$ & $1.82(1 \mathrm{H}, \mathrm{m})$ & 32.0 & - & 143.7 \\
\hline $9^{\prime}$ & - & 38.1 & $5.50(1 \mathrm{H}, \mathrm{td}, 6.6,0.9)$ & 118.6 \\
\hline $10^{\prime}$ & $2.37(1 \mathrm{H}, \mathrm{d}, 10.8)$ & 38.4 & - & 73.7 \\
\hline $11^{\prime}$ & $3.87(1 \mathrm{H}, \mathrm{d}, 8.6, \mathrm{H}-\mathrm{a}) ; 3.83(1 \mathrm{H}, \mathrm{d}, 8.6, \mathrm{H}-\mathrm{b})$ & 72.8 & $4.60(2 \mathrm{H}, \mathrm{dd}, 6.6,1.8)$ & 65.6 \\
\hline $12^{\prime}$ & $0.96(3 \mathrm{H}, \mathrm{d}, 6.9)$ & 15.5 & $1.79(3 \mathrm{H}, \mathrm{s})$ & 17.1 \\
\hline $13^{\prime}$ & $1.10(3 \mathrm{H}, \mathrm{s})$ & 24.7 & $1.04(3 \mathrm{H}, \mathrm{s})$ & 28.3 \\
\hline $14^{\prime}$ & $1.05(3 \mathrm{H}, \mathrm{s})$ & 26.3 & $0.80(3 \mathrm{H}, \mathrm{s})$ & 15.1 \\
\hline $15^{\prime}$ & $1.10(3 \mathrm{H}, \mathrm{s})$ & 20.9 & $1.18(3 \mathrm{H}, \mathrm{s})$ & 23.3 \\
\hline 2 & - & 161.4 & - & 161.5 \\
\hline 3 & $6.24(1 \mathrm{H}, \mathrm{d}, 9.5)$ & 112.6 & $6.25(1 \mathrm{H}, \mathrm{d}, 9.5)$ & 112.7 \\
\hline 4 & $7.63(1 \mathrm{H}, \mathrm{d}, 9.5)$ & 143.6 & $7.64(1 \mathrm{H}, \mathrm{d}, 9.5)$ & 143.7 \\
\hline 5 & $7.35(1 \mathrm{H}, \mathrm{d}, 8.6)$ & 128.8 & $7.37(1 \mathrm{H}, \mathrm{d}, 8.5)$ & 128.9 \\
\hline 6 & $6.85(1 \mathrm{H}, \mathrm{d}, 8.6,2.2)$ & 113.3 & $6.85(1 \mathrm{H}, \mathrm{dd}, 8.5,2.3)$ & 113.4 \\
\hline 7 & - & 163.1 & - & 162.3 \\
\hline 8 & $6.81(1 \mathrm{H}, \mathrm{d}, 2.2)$ & 101.6 & $6.83(1 \mathrm{H}, \mathrm{d}, 2.3)$ & 101.8 \\
\hline 9 & - & 156.1 & - & 156.0 \\
\hline 10 & - & 113.1 & - & 113.2 \\
\hline
\end{tabular}

analysis, $[\alpha]_{D}$, and ECD spectroscopy). Compounds 1 and 10 are reported for the first time, and compounds 2-9 and 13-15 were obtained for the first time from Awei. Because of the complicated chiral centers in sesquiterpene coumarins, there is still some confusion about the elucidation of their stereostructures. We analyzed the stereochemistry by 2D NMR, ECD, and single-crystal $\mathrm{X}$-ray analysis. The results established the absolute configurations of compounds $1-5$ and 10 , and for the first time clarified the absolute configurations of compounds 2,4 , and 5 , which had been reported in the literature only with their relative configurations $[22,23]$. Moreover, a detailed analysis of the 2D-NMR spectra produced a systematic assignment of compounds 2-6 for the first time.

Compound 1, obtained as colorless oil with $[\alpha]_{D}^{20}+39.8$ (c 1.13, $\mathrm{CHCl}_{3}$ ), has a molecular formula of $\mathrm{C}_{24} \mathrm{H}_{30} \mathrm{O}_{4}$, determined by HR-ESI-MS ion at $\mathrm{m} / \mathrm{z} 405.2037[\mathrm{M}+\mathrm{Na}]^{+}$: (calcd. 405.2036 for $\mathrm{C}_{24} \mathrm{H}_{30} \mathrm{NaO}_{4}$ ).

The ${ }^{1} \mathrm{H}$ NMR spectrum of compound 1 showed signals of a typical 7-O-substituted coumarin at $\delta_{\mathrm{H}} 7.63(1 \mathrm{H}, \mathrm{d}, J=9.5 \mathrm{~Hz}, \mathrm{H}-4)$, $7.35(1 \mathrm{H}, \mathrm{d}, J=8.6 \mathrm{~Hz}, \mathrm{H}-5), 6.85(1 \mathrm{H}, \mathrm{d}, J=8.6,2.2 \mathrm{~Hz}, \mathrm{H}-6)$, $6.81(1 \mathrm{H}, \mathrm{d}, J=2.2 \mathrm{~Hz}, \mathrm{H}-8)$ and $6.24(1 \mathrm{H}, \mathrm{d}, J=9.5 \mathrm{~Hz}, \mathrm{H}-3)$. We observed resonances of olefin at $\delta_{\mathrm{H}} 5.50\left(1 \mathrm{H}, \mathrm{t}, J=3.3 \mathrm{~Hz}, \mathrm{H}-6^{\prime}\right)$, an oxygenated methylene group at $\delta_{\mathrm{H}} 3.87(1 \mathrm{H}, \mathrm{d}, J=8.6 \mathrm{~Hz}, \mathrm{H}$ $\left.11^{\prime} \mathrm{a}\right), 3.83\left(1 \mathrm{H}, \mathrm{d}, J=8.6 \mathrm{~Hz}, \mathrm{H}-11^{\prime} \mathrm{b}\right)$ and an oxygenated methine group at $\delta_{\mathrm{H}} 3.47\left(1 \mathrm{H}, \mathrm{s}, \mathrm{H}-3^{\prime}\right)$. The ${ }^{1} \mathrm{H}$ NMR spectrum also exhibited signals for three tertiary methyl groups at $\delta_{\mathrm{H}} 1.10(3 \mathrm{H}, \mathrm{s}$, Me$\left.13^{\prime}\right), 1.10\left(3 \mathrm{H}, \mathrm{s}, \mathrm{Me}-15^{\prime}\right), 1.05$ (3H, s, Me-14') and one secondary methyl group at $\delta_{\mathrm{H}} 0.96\left(3 \mathrm{H}, \mathrm{d}, J=6.9 \mathrm{~Hz}, \mathrm{Me}-12^{\prime}\right)$. Twenty-four carbon signals were observed in the ${ }^{13} \mathrm{C}$ NMR spectrum of compound 1 , including nine carbons for typical umbelliferone skeleton and fifteen carbons ascribable to a sesquiterpene moiety. The spectral data of 1D NMR ( $\bullet$ Table 1 ) suggested that compound 1 was a sesquiterpene coumarin, which is a characteristic skeleton for the genus Ferula. HSQC and HMBC spectra further clarified the planar structure.

In the HMBC experiment ( $\vee$ Fig. 2 ), the connection between sesquiterpene and coumarin moieties was proven to be C-11'-OC-7 by observed long-range correlations between $\delta_{\mathrm{H}} 3.87(1 \mathrm{H}, \mathrm{d}$, $\left.J=8.6 \mathrm{~Hz}, \mathrm{H}-11^{\prime} \mathrm{a}\right), 3.83\left(1 \mathrm{H}, \mathrm{d}, J=8.6 \mathrm{~Hz}, \mathrm{H}-11^{\prime} \mathrm{b}\right)$ and $\delta_{\mathrm{C}} 163.1$ (C-7), $32.0\left(\mathrm{C}-8^{\prime}\right), 38.1\left(\mathrm{C}-9^{\prime}\right)$. In addition, the correlations from signals at $\delta_{\mathrm{H}} 1.10\left(3 \mathrm{H}, \mathrm{s}, \mathrm{Me}-13^{\prime}\right), 1.06\left(3 \mathrm{H}, \mathrm{s}, \mathrm{Me}-14^{\prime}\right)$ to the carbon resonance at $\delta_{C} 76.7\left(C-3^{\prime}\right), 42.3\left(C-4^{\prime}\right), 142.6\left(C-5^{\prime}\right)$ revealed 

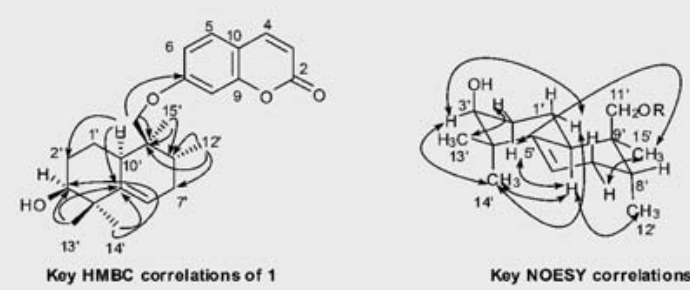

Key NOESY correlations of 1
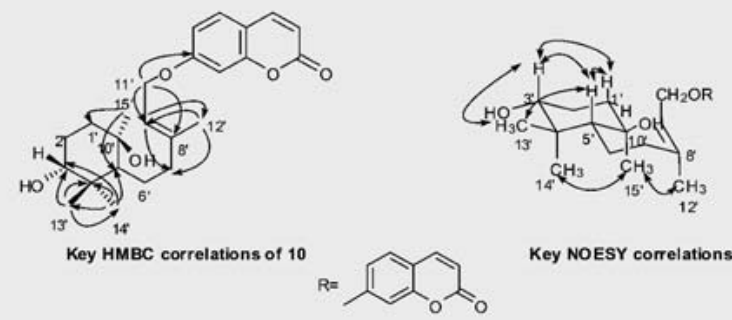

Key NOESY correlations of 10

- Fig. 2 Key HMBC and NOESY correlations of compounds 1 and 10.

$\mathbf{A}$

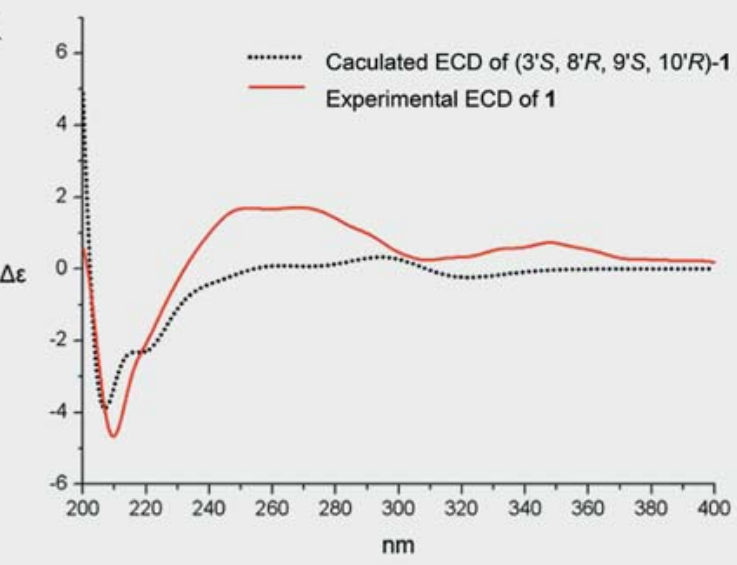

B $\left.\quad{ }^{30}\right] \quad \ldots \ldots . . . . \quad$ Caculated $E C D$ of $\left(3^{\prime} R, 5^{\prime} R, 10^{\prime} R\right)-10$

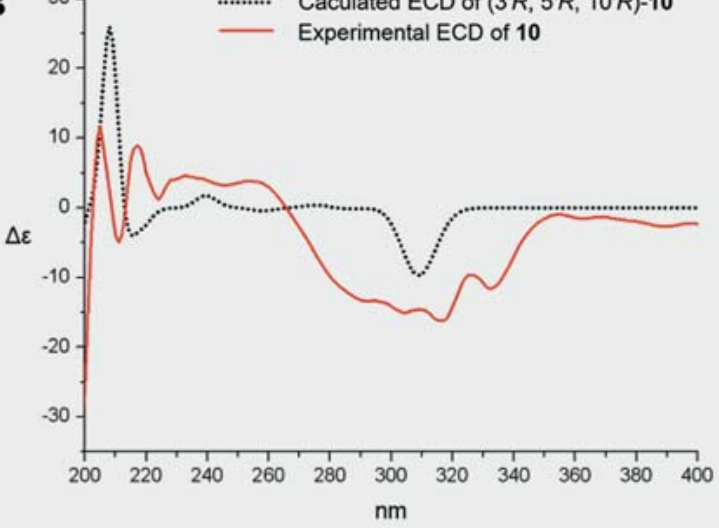

- Fig. 3 Comparison of calculated and experimental ECD spectrum of compound 1 (A) and compound 10 (B). the presence of a hydroxyl group at $\mathrm{C}-3^{\prime}$. The correlations between $\delta_{\mathrm{H}} 0.96\left(3 \mathrm{H}, \mathrm{d}, J=6.9 \mathrm{~Hz}, \mathrm{Me}-12^{\prime}\right)$ and $\delta_{\mathrm{C}} 31.7\left(\mathrm{C}-7^{\prime}\right), 32.0$ $\left(C-8^{\prime}\right), 38.1\left(C-9^{\prime}\right)$ fixed the methyl group Me-12 at C-8'. The remaining methyl groups Me-15' were established at C-9' by the HMBC correlations between $\delta_{\mathrm{H}} 1.10\left(3 \mathrm{H}, \mathrm{s}\right.$, Me-15') and $\delta_{\mathrm{C}} 32.0$ (C-8'), 38.1 (C-9'), $38.4\left(\mathrm{C}-10^{\prime}\right), 72.8\left(\mathrm{C}-11^{\prime}\right)$.

In the NOESY spectrum ( $\vee$ Fig. 2 ), we determined that the configurations of $\mathrm{OH}-3^{\prime}, \mathrm{CH}_{2}-11^{\prime}$ were $\beta$-oriented, based on the correlations between $\mathrm{H}-3^{\prime}$ and $\mathrm{Me}-14^{\prime}, \mathrm{H}-1^{\prime}$ eq; $\mathrm{H}-10^{\prime}$ and Me-12', $\mathrm{H}$ 2'ax, Me-14'; Me-15' and H-2'ax, H-7'eq and that the configurations of $\mathrm{H}-3^{\prime}, \mathrm{H}-10^{\prime}$, Me-12', Me-15' were $\alpha$-oriented. We also determined that the relative configuration of compound 1 was $3^{\prime} S^{*}$, $8^{\prime} R^{*}, 9^{\prime} S^{*}, 10^{\prime} R^{*}$, and a comparison of experimental and calculated ECD spectra further established the absolute configuration. Preferred conformers within a $20 \mathrm{kcal} / \mathrm{mol}$ energy threshrold were revealed by a conformational search with the Discovery Studio 3.0 program using a systematic method. We found no imaginary frequencies when we subjected these conformers to geometrical optimization and energy calculation using TDDFT with the B3LYP function and 6-31 G (d) combined with calculation of vibrational modes to confirm these minima. Calculations of the ECD spectra for these conformers were performed as described above. - Fig. 3 A shows the weighted ECD spectrum in $\mathrm{MeOH}$. The calculated ECD spectrum of an isomer $\left(3^{\prime} S, 8^{\prime} R, 9^{\prime} S, 10^{\prime} R\right)$ of compound 1 closely matched the experimental data, in particular a negative Cotton effect (CE) in the $200-220 \mathrm{~nm}$ region and a positive CE in the regions of $240-270 \mathrm{~nm}, 290-310 \mathrm{~nm}$ and $340-$ $360 \mathrm{~nm}$ [24]. Thus, the authors determined that the absolute configuration of compound 1 was $3^{\prime} S, 8^{\prime} R, 9^{\prime} S, 10^{\prime} R$. We established the structure of compound 1 as shown in > Fig. 1 and identified it as $\left(3^{\prime} S, 8^{\prime} R, 9^{\prime} S, 10^{\prime} R\right)$-sinkianol A. Analysis of the 1D and 2D NMR spectra permitted the assignment of the ${ }^{1} \mathrm{H}$ and ${ }^{13} \mathrm{C}-\mathrm{NMR}$ spectroscopic data listed in $>$ Table $\mathbf{1}$.

Compound 10 , obtained as white crystal with $[\alpha]_{D}^{20}-10.9(c$ $0.76, \mathrm{CHCl}_{3}$ ), has a molecular formula of $\mathrm{C}_{24} \mathrm{H}_{32} \mathrm{O}_{5}$ established by HR-ESI-MS ion at $\mathrm{m} / \mathrm{z} 423.2140[\mathrm{M}+\mathrm{Na}]^{+}$: (calcd. 423.2142 for $\mathrm{C}_{24} \mathrm{H}_{32} \mathrm{NaO}_{5}$ ).

The ${ }^{1} \mathrm{H}$ NMR spectrum of compound 10 exhibited the signals of a typical 7-O-substituted coumarin at $\delta_{\mathrm{H}} 7.64(1 \mathrm{H}, \mathrm{d}, J=9.5 \mathrm{~Hz}, \mathrm{H}$ 4), $7.37(1 \mathrm{H}, \mathrm{d}, J=8.5 \mathrm{~Hz}, \mathrm{H}-5), 6.85(1 \mathrm{H}, \mathrm{dd}, J=8.5,2.3 \mathrm{~Hz}, \mathrm{H}-6)$, $6.83(1 \mathrm{H}, \mathrm{d}, J=2.3 \mathrm{~Hz}, \mathrm{H}-8)$ and $6.25(1 \mathrm{H}, \mathrm{d}, J=9.5 \mathrm{~Hz}, \mathrm{H}-3)$. We also observed the signals of olefin at $\delta_{\mathrm{H}} 5.50(1 \mathrm{H}, \mathrm{td}, J=6.6$, $\left.0.9 \mathrm{~Hz}, \mathrm{H}-9^{\prime}\right)$ and an oxygenated methine group at $\delta_{\mathrm{H}} 3.32(1 \mathrm{H}$, $\left.\mathrm{dd}, J=11.0,4.0 \mathrm{~Hz}, \mathrm{H}-3^{\prime}\right)$. The ${ }^{1} \mathrm{H}$ NMR showed resonances of four tertiary methyl groups at $\delta_{\mathrm{H}} 1.79\left(3 \mathrm{H}, \mathrm{s}, \mathrm{Me}-12^{\prime}\right), 1.18(3 \mathrm{H}, \mathrm{s}$, Me$\left.15^{\prime}\right), 1.04\left(3 \mathrm{H}, \mathrm{s}, \mathrm{Me}-13^{\prime}\right)$ and $0.80\left(3 \mathrm{H}, \mathrm{s}, \mathrm{Me}-14^{\prime}\right)$. The ${ }^{13} \mathrm{C}$ NMR spectrum of compound 10 displayed twenty-four carbon signals, nine peaks for a typical umbelliferone skeleton and the others ascribable to a sesquiterpene moiety. The ${ }^{1} \mathrm{H}$ and ${ }^{13} \mathrm{C}$ NMR spectral data ( $\vee$ Table 1 ) suggested that compound 10 was a sesquiterpene coumarin. HSQC and HMBC spectra further clarified the plane structure.

The HMBC experiment $(\triangleright$ Fig. 2 ) proved that the connection between sesquiterpene moiety and coumarin was C-11'-O-C-7, based on the observation of long-range correlations between $\delta_{\mathrm{H}}$ $4.60\left(2 \mathrm{H}\right.$, dd, $\left.J=6.6,1.8 \mathrm{~Hz}, \mathrm{CH}_{2}-11^{\prime}\right)$ and $\delta_{\mathrm{C}} 162.3$ (C-7), 143.7 $\left(\mathrm{C}-8^{\prime}\right)$, $118.6\left(\mathrm{C}-9^{\prime}\right)$. Long range $\mathrm{HMBC}$ correlations from the pro- 
- Table 2 Effects of extracts and isolated sesquiterpene coumarins from $F$. sinkiangensis on NO production by LPS-activated microglia cells (Mean \pm SEM).

\begin{tabular}{|c|c|c|c|}
\hline Sample name & $\mathrm{IC}_{50} \mathrm{a}^{\mathrm{a}}$ & Sample name & $1 C_{50}{ }^{a}$ \\
\hline Ext-1 ${ }^{b}$ & $1.66 \pm 1.10$ & Compound 7 & $37.88 \pm 1.71$ \\
\hline Ext- $2^{b}$ & $2.72 \pm 1.06$ & Compound 8 & $6.93 \pm 1.73$ \\
\hline Ext-3 b & $11.18 \pm 2.07$ & Compound $9^{b}$ & $19.88 \pm 1.65$ \\
\hline Ext- $4^{b}$ & $8.83 \pm 1.29$ & Compound 11 & $45.37 \pm 1.89$ \\
\hline Compound 1 & $>50$ & Compound 12 & $31.43 \pm 1.55$ \\
\hline Compound 2 & $>50$ & Compound $13^{\mathrm{b}}$ & $10.50 \pm 1.12$ \\
\hline Compound 3 & $21.34 \pm 1.55$ & Compound $14^{\mathrm{b}}$ & $5.95 \pm 1.27$ \\
\hline Compound $4^{\mathrm{b}}$ & $4.96 \pm 1.39$ & Compound $15^{\mathrm{b}}$ & $47.43 \pm 1.6$ \\
\hline Compound 5 & $31.61 \pm 1.47$ & Compound 16 & $>50$ \\
\hline Compound 6 & $>50$ & minocycline $^{c}$ & $37.04 \pm 2.09$ \\
\hline
\end{tabular}

${ }^{\mathrm{a}} \mathrm{IC}_{50}\left(\mu \mathrm{g} / \mathrm{mL}\right.$ for extracts and $\mu \mathrm{M}$ for compounds). ${ }^{\mathrm{b}}$ Ext-1-4 showed cytotoxicity at $50 \mu \mathrm{g} / \mathrm{mL}$; Compound 4, 9, 13-15 showed cytotoxicity at $50 \mu \mathrm{M}$. c Positive control

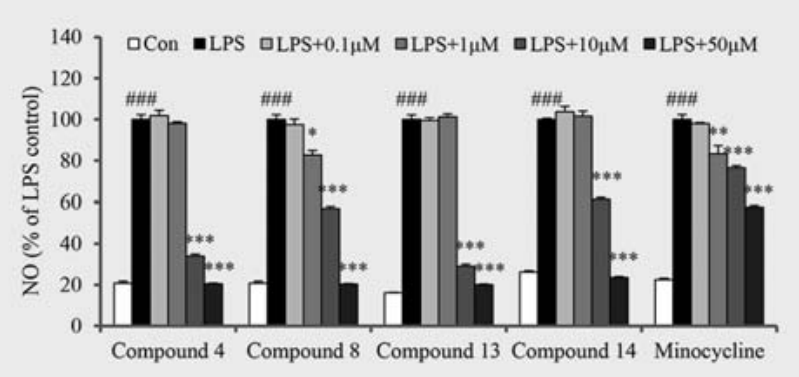

- Fig. 4 BV-2 cell viability assay and anti-neuroinflammatory activities of compounds 4, 8, 13, 14 from F. sinkiangensis on LPS-induced NO production in BV-2 microglial cells. Each bar represents the means $\pm S E$ of three independent experiments. Significance: ${ }^{*} \mathrm{P}<0.05,{ }^{* *} \mathrm{p}<0.01,{ }^{* * *} \mathrm{p}<0.001$, compared to LPS groups. $\# \# \mathrm{P}<0.001$, compared to control groups.

ton signals at $\delta_{\mathrm{H}} 1.04\left(3 \mathrm{H}, \mathrm{s}, \mathrm{Me}-13^{\prime}\right), 0.80\left(3 \mathrm{H}, \mathrm{s}, \mathrm{Me}-14^{\prime}\right)$ to the carbon resonance at $\delta_{\mathrm{C}} 78.4\left(\mathrm{C}-3^{\prime}\right), 40.6\left(\mathrm{C}-4^{\prime}\right), 55.5\left(\mathrm{C}-5^{\prime}\right)$ revealed the location of a hydroxyl group at $\mathrm{C}-3^{\prime}$. A tertiary methyl Me-15'was fixed at C-10' because of correlations between $\delta_{H} 1.18$ $\left(3 \mathrm{H}, \mathrm{s}, \mathrm{Me}-15^{\prime}\right)$ and $\delta_{\mathrm{C}} 55.5\left(\mathrm{C}-5^{\prime}\right), 41.2\left(\mathrm{C}-1^{\prime}\right)$. We established the remaining methyl groups Me- $12^{\prime}$ at $\mathrm{C}-8^{\prime}$ carbon based on $\mathrm{HMBC}$ correlation between $\delta_{\mathrm{H}} 1.79\left(3 \mathrm{H}, \mathrm{s}, \mathrm{Me}-12^{\prime}\right)$ and $\delta_{\mathrm{C}} 42.7\left(\mathrm{C}-7^{\prime}\right)$, $118.6\left(C-9^{\prime}\right)$.

In the NOESY spectrum ( $\bullet$ Fig. 2 ), the correlations between $\mathrm{H}$ 3' and H-1'ax, H-5'; Me-13' and H-3', H-5'; Me-15' and Me-12', Me-14' proved that $\mathrm{H}-3^{\prime}$ was $\beta$-oriented and that $\mathrm{OH}-3^{\prime}$, Me-15' were $\alpha$-oriented. Based on the above data, the relative configuration of compound 10 was established as $3^{\prime} R^{*}, 5^{\prime} R^{*}, 10^{\prime} R^{*}$. We further established the absolute configuration of compound 10 by comparison of experimental and calculated ECD spectra. The calculation of the ECD spectra was performed in the same manner as with compound 1. - Fig. 3 B shows the weighted ECD spectrum in $\mathrm{MeOH}$. The calculated ECD spectrum of an isomer $\left(3^{\prime} R, 5^{\prime} R, 10^{\prime} R\right)$ in compound 10 closely matched the experimental data, in particular the positive CE in the $200-210 \mathrm{~nm}$ region, and the negative CE in the regions of $210-215 \mathrm{~nm}$ and $290-330 \mathrm{~nm}$. Differences between the calculated and experimental spectra were apparently due to minor differences between the calculated and solution conformers of this flexible molecule [24]. Thus, we established that the structure of compound 10 was $\left(3^{\prime} R, 5^{\prime} R, 10^{\prime} R\right)$-sinkianol B, as shown in > Fig. 1.

We identified fourteen known sesquiterpene coumarins as $\left(5^{\prime}\right.$ $S, 8^{\prime} R, 9^{\prime} S, 10^{\prime} R$ )-ferukrinone (2) [22], ferukrin (3) [25], (3'S, $5^{\prime} S, 8^{\prime}$ $\left.R, 9^{\prime} S, 10^{\prime} R\right)$-kellerin (4), (3'S, $\left.5^{\prime} S, 8^{\prime} R, 9^{\prime} S, 10^{\prime} R\right)$-deacetylkellerin (5) [23], farnesiferol A (6) [26], farnesiferone A (7) [27], gummo$\sin (8)$ [28], polyanthinin (9) [26], farnesiferol B (11) [29], farnesiferol C (12) [30], galbanic acid (13) [31], methyl galbanate (14) [20], karatavicinol (15) [32], and umbelliprenin (16) [33] ( $\triangleright$ Fig. 1). Comparison of experimental and simulated ECD spectra established the absolute configurations of compounds 2-5. This is the first confirmation of the absolute configurations of compounds 2, 4 and 5, which had been reported previously as relative structures. The relative configuration of compound 2 was established by NOESY and X-ray crystallographic analysis as $5^{\prime} R^{*}, 8^{\prime}$ $S^{*}, 9^{\prime} R^{*}, 10^{\prime} S^{*}$ (Fig. 13S, Supporting Information). We then established the absolute configuration of compound 2 as $5^{\prime} S, 8^{\prime} R$, $9^{\prime} S, 10^{\prime} R$ (Fig. 14 S, Supporting Information) by means of the calculated and experimental ECD spectra. Based on the relative configuration from the NOESY experiment, we determined that the absolute configuration of compound 3 was $3^{\prime} R, 5^{\prime} S, 8^{\prime} R, 9^{\prime} S, 10^{\prime}$ $R$ with the calculated and experimental ECD spectra shown in Fig. 14S, Supporting Information. We used the same procedure to determine that $3^{\prime} S, 5^{\prime} S, 8^{\prime} R, 9^{\prime} S, 10^{\prime} R$ was the absolute configuration of both compound 4 and compound 5 (Fig. 14 S, Supporting Information).

By monitoring LPS-induced NO production, we assayed the anti-neuroinflammatory activities of the extract and the sixteen sesquiterpene coumarins in BV-2 microglial cells ( $\vee$ Table 2 and Fig. 15 S, Supporting Information). We assayed the cytotoxic activities of tested samples by MTT method in order to avoid the possible effect of reduced viability on NO release. To focus on the effective fraction, we partitioned the chloroform extract into three fractions (Ext-2, Ext-3 and Ext-4) according to the polarity by using flash silica column chromatography. The result indicated that the chloroform extract (Ext-1), low polar fraction (Ext-2) and moderate polar fraction (Ext-3) could reduce LPS-induced NO production significantly at $10 \mu \mathrm{g} / \mathrm{mL}$. None of the extracts exhibited a toxic effect on BV-2 microglial cells at $0.1,1,10 \mu \mathrm{g} / \mathrm{mL}$ (Fig. $15 \mathrm{~S}$, Supporting Information).

As for the sixteen sesquiterpene coumarins that we isolated, compounds 4, 8, 13 and 14 exhibited significant anti-neuroinflammatory activities with $\mathrm{IC}_{50}$ values at 4.96, 6.93, 10.50 and $5.95 \mu \mathrm{M}$, respectively ( $\bullet$ Table 2 , Fig. 4). Compounds 3, 5, 7, 9, 11,12 and 15 could reduce the production of NO greatly with $\mathrm{IC}_{50}$ values ranging from 19.88 to $47.43 \mu \mathrm{M}$, and compounds 1 , 2, 6 and 16 showed significant inhibiting activities at $50 \mu \mathrm{M}(\triangleright$ Table 2, Fig. $15 \mathrm{~S}$, Supporting Information). 
The phytochemical result indicated that sesquiterpene coumarins are the main bioactive components of Awei produced from $F$. sinkiangensis. The identified sesquiterpene coumarins can be divided into bicyclic (compounds 1-9), monocyclic (compounds 10-14) and chain sesquiterpene coumarins (compounds 15 and 16) according to the differences in the structures of sesquiterpene moieties ( $\triangleright$ Fig. 1).

Considering the structural characteristics and anti-neuroinflammatory effects, we can summarize the brief SAR as follows: Firstly, the substitution at $\mathrm{C}^{-3}{ }^{\prime}$ in bicyclic sesquiterpene coumarins, which possessed the substitution of methyl and hydroxyl at $C-8^{\prime}(R)$, may play an important role in mediating anti-neuroinflammatory activity. The ability of substituted groups at $C-3^{\prime}$ to enhance the activity followed the sequential order of acetoxyl group, $\alpha$-hydroxy group, $\beta$-hydroxy group, and carbonyl group, but the order is different in bicyclic sesquiterpene coumarins with a terminal double bond substituted at C $-8^{\prime}$. The order for those is $\beta$-hydroxy group, acetoxyl group, carbonyl group, and $\alpha$-hydroxy group. Secondly, for monocyclic sesquiterpene coumarins, the crack position of the rings in the sesquiterpene moieties could affect the activities. Compounds 13 and 14, with the A ring cracked, exhibited a better anti-neuroinflammatory effect than compounds 11 and 12, with the B ring cracked. Furthermore, we confirmed that the presence of an oxygen bridge in the A ring in monocyclic sesquiterpene coumarins could improve the activity. Finally, the chain sesquiterpene coumarins, compounds 15 and 16, exhibited weak activities. The research therefore suggests that the ring in a sesquiterpene moiety is necessary for the antineuroinflammatory effect.

It can be concluded that the major constituent ( $3^{\prime} S, 5^{\prime} S, 8^{\prime} R, 9^{\prime} S$, $10^{\prime} R$ )-kellerin (compound 4, 1.5\%, w/w) might be an effective component of Awei produced from $F$. sinkiangensis. We also used quantitative real-time PCR ( $q R T-P C R)$ to investigate the primary mechanism of compound 4. The research revealed that $\left(3^{\prime} S, 5^{\prime} S\right.$, $8^{\prime} R, 9^{\prime} S, 10^{\prime} R$ )-kellerin could significantly inhibit the mRNA expression of inflammatory factors TNF- $\alpha$, IL-6, IL- $1 \beta$ induced by LPS in BV2 microglial cells at concentrations of $1-10 \mu \mathrm{M}$. And it could also significantly inhibit mRNA expression of inflammatory factor COX2 induced by LPS in BV2 microglial cells at concentration of 3$10 \mu \mathrm{M}$.

\section{Material and Methods}

\section{General experimental procedures}

The authors used a Shimadzu QP-2010 Plus device to measure mass spectra. NMR spectra were recorded on Bruker ARX-300 and ARX-600 spectrometers; $\delta$ in ppm rel. to $\mathrm{Me}_{4} \mathrm{Si}$ as internal standard; J in Hz. HR-EST-MS: Bruker micro TOF-Q mass spectrometer; in $\mathrm{m} / \mathrm{z}$ (rel.\%). ECD spectra recorded in MeOH on MOS-450 spectrometer. Silica gel ( $\mathrm{SiO}_{2}:$ 200-300 mesh), Sephadex LH-20 (Pharmacia, Co.), and ODS (10 30 $\mu \mathrm{m})$ were used for column chromatography. Semi-preparative HPLC was carried out on a YMC ODS C- 18 column $(250 \mathrm{~mm} \times 10 \mathrm{~mm}, 10 \mu \mathrm{m}$, ODS-A $)$ and on a Shimadzu SPD-10 A UV detector, and silica gel GF $_{254}$ was used for TLC ( $\mathrm{SiO}_{2}$ : 200-300 mesh). We visualized the chromatograms under UV light (at 254 and $365 \mathrm{~nm}$ ) before spraying a sul- furic acid-ethanol (10\%) spray reagent. $\mathrm{CDCl}_{3}$, DMSO, and thiazolyl blue (MTT) were obtained from Sigma-Aldrich, and Bio-Rad Laboratories provided the reagents for the qRT-PCR experiments. All other chemicals and solvents for this experiment were of analytical grade or higher.

\section{Materials}

The gum resin of $F$. sinkiangensis was collected in Xinjiang Province, China, during June 2012. Prof. Jie Xue identified the plant material, and a voucher specimen (No.81060332) is deposited in the School of Traditional Chinese Materia Medica at Shenyang Pharmaceutical University. Minocycline (purity >98\%) was purchased from Melone Pharmaceutical Co., Ltd.

\section{Extraction and isolation}

Dried gum resin of $F$. sinkiangensis $(900 \mathrm{~g})$ was extracted with $\mathrm{CHCl}_{3}(3 \times 2.7 \mathrm{~L}, 2 \mathrm{~h}$ each $)$ under reflux, and the organic solvent was concentrated to afford a crude extract $(558 \mathrm{~g}) .300 \mathrm{~g}$ of the extract were subjected to a silica gel column, eluted with a gradient of PE/acetone, to afford 10 fractions (Fr.1-Fr.10). Compound 16 (16.0 mg, 98.1\%) was isolated from Fr.1 by silica gel CC and recrystallization. Fr.2 was separated by ODS CC and semi-preparative HPLC to yield compound 1 (17.6 mg, $98.3 \%$,), and compound 14 (20.5 mg, 98.1\%). Fr.3 was fractionated by silica gel CC to yield compound 12 (1.6 g, 99.0\%) and compound 9 (20.5 mg, 97.5\%). Fr.4 was subjected to silica gel CC to yield compound $7(728.8 \mathrm{mg}$, $98.3 \%), 11(2.0 \mathrm{~g}, 98.2 \%)$ and $8(16.9 \mathrm{mg}, 96.9 \%)$. Then compound $4(7.25 \mathrm{~g}, 97.4 \%)$ was purified from Fr.5 by CC and ODS CC. Fr.6 was subjected to silica gel CC and then purified by HPLC to yield compound $6(250.0 \mathrm{mg}, 98.1 \%)$ and compound 13 (40.2 mg, 98.7\%). Fr.8 was subjected to ODS CC to yield compound 3 (17.0 mg, $97.1 \%$ ), and then purified by semi-preparative HPLC to yield compound 2 (23.6 mg, 97.4\%), compound 5 (20.5 mg, 97.3\%) and compound 15 (42.7 mg, 98.2\%). Fr.10 was purified by silica gel CC, recrystallization, and PTLC to yield compound 10 (42.1 mg, 96.8\%). For details on the isolation process, see Supporting Information.

\section{Conformational analysis, geometrical optimization, and ECD calculation}

Conformers of compounds $\mathbf{1 - 5}$ and compound 10 were generated by conformational search with the Discovery Studio 3.0 program, using the method of systematic search within a relative energy threshrold of $20 \mathrm{kcal} / \mathrm{mol}$. The conformers were chosen for geometrical optimization by AM1 method and for energy calculation by density function theory (DFT) with the B3LYP functional and the 6-31 G (d) basis-set with the Gaussian 09 program [34, 35].

We performed the vibrational analysis at the same level to confirm minima. TD-DFT/B3LYP/6-31 G(d) in $\mathrm{MeOH}$ using the SCRF (self-consistent reaction field) method with a CPCM (conductorlike polarizable continuum) solvent model was employed to calculate the excitation energy (denoted by wavelength in $\mathrm{nm}$ ) and rotatory strength $\mathrm{R}$ in the dipole velocity (Rvel) and dipole length (Rvel) forms. ECD curves were calculated based on rotatory strengths using a half bandwidth of $0.2 \mathrm{eV}$ with conformers of compounds 1-5 and compound 10 using Gaussian 2.2 software [35]. To generate 

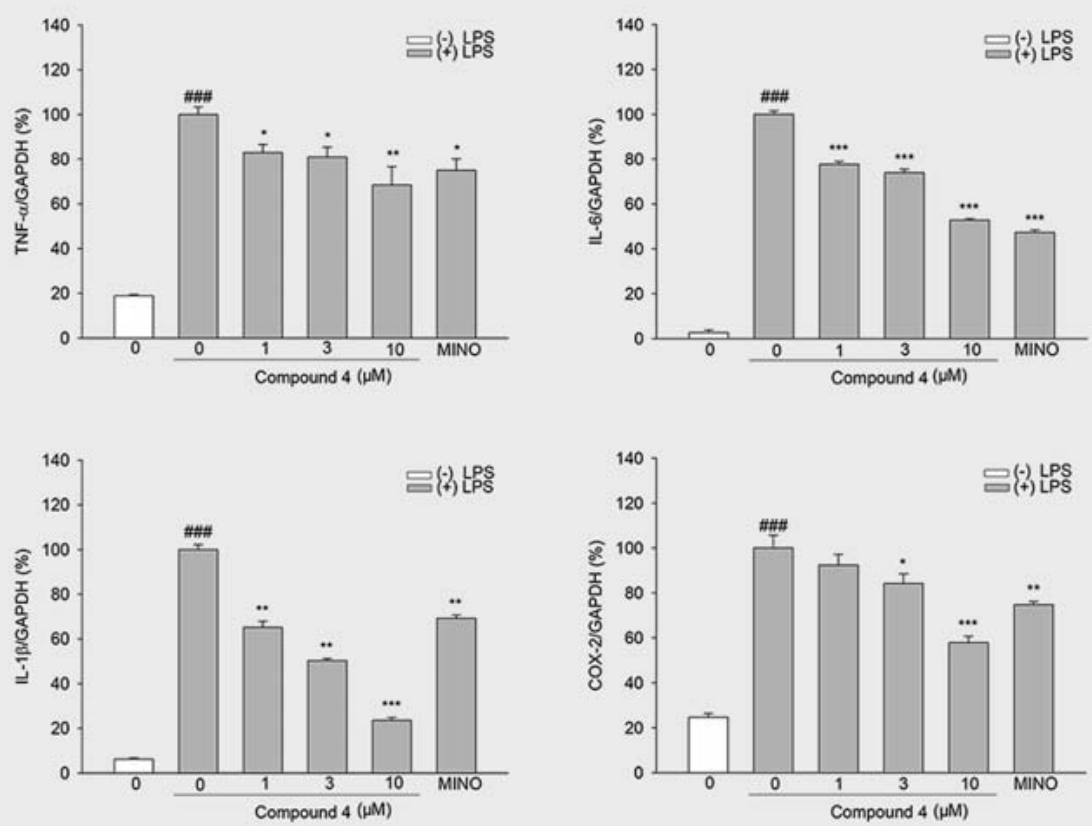

- Fig. 5 Effect of compound 4 on LPS-induced mRNA expressions of TNF- $\alpha$, IL-6, COX-2 and IL- $1 \beta$ in BV-2 microglial cells. Each bar represents the

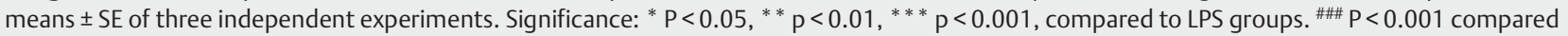
to control groups).

the final spectrum of a molecule, we Boltzmann-averaged all of the simulated spectra of the generated conformers.

\section{Assay of anti-inflammatory activities in BV-2 cells}

Determination of cell viability: Cell viability was evaluated by MTT reduction assay [36]. In brief, cells were seeded into 96-well microtiter plates. After treatment with tested samples for $24 \mathrm{~h}$, cells were incubated with MTT $(0.25 \mathrm{mg} / \mathrm{mL})$ for $4 \mathrm{~h}$ at $37^{\circ} \mathrm{C}$. The supernatant was removed and then the formazan crystals in the cells were dissolved in DMSO. Plates were read on an aplate reader (Bio-Tek) at $490 \mathrm{~nm}$.

Nitrite assay: The accumulation of nitrite in culture supernatant fluids was measured by Griess reaction [36]. Cells were plated into 96-well microtiter plates and treated with tested samples in presence of LPS (100 ng/mL) for $24 \mathrm{~h}$. $50 \mu \mathrm{L}$ of culture supernatant fluids were mixed with $50 \mu \mathrm{L}$ Griess reagent at room temperature; the absorbance at $540 \mathrm{~nm}$ was determined after $15 \mathrm{~min}$.

\section{Quantitative real-time PCR}

BV-2 microglial cells were treated with compound $4(1,3,10 \mu \mathrm{M})$ in presence of LPS $(100 \mathrm{ng} / \mathrm{mL})$ for $4 \mathrm{~h}$, total RNA was extracted with Trizol (Invitrogen) according to the manufacturer's protocol, and qRT-PCR assays were performed with the CFX Connect ${ }^{\mathrm{TM}}$ realtime PCR detection system (Bio-Rad) using total RNA and the GoTaq one-step real-time PCR kit with SYBR green (Promega). The following primers were used: TNF- $\alpha$, sense primer: $5^{\prime}$-CCCTCACACTCAGATCATCTTCT-3', antisense primer: 5'-GCTACGACGTGGGCTACAG-3'; IL-6, sense primer: 5'-TAGTCCTTCCTACCCCAATTTCC-3', antisense primer: 5'-TTGGTCCTTAGCCACTCCTTC-
3'; IL-1 $\beta$, sense primer: 5'-GCAACTGTTCCTGAACTCAACT-3', antisense primer: 5'-ATCTTTTGGGGCGTCAACT-3'; COX-2, sense primer: 5'-GACAGATCATAAGCGAGGA-3', antisense primer: 5'CACAGCAAACTGCAGGTTC-3'; GAPDH, sense primer: 5'-AGGTCGGTGTGAACGGATTTG-3', antisense primer: 5'-TGTAGACCATGTAGTTGAGGTCA-3'. The gene expression values were normalized to those of GAPDH, see $>$ Fig. 5.

\section{Supporting Information}

Details on the isolation procedure, spectral assignments of known compounds, the X-ray (MoK $\alpha$ ) crystallographic structure of compound 2, the comparison of calculated and experimental ECD spectra of compounds $2-5$, and the BV-2 cell viability assay and anti-neuroinflammatory activities of extracts, fractions and identified compounds are available as Supporting Information.

\section{Acknowledgment}

The supporters of this work include the National Natural Science Foundation of China (U1403102, 81173531, 81473330), the Shenyang Science and Technology Research Project (F15-1991-26), the Research Project for Key Laboratory of Liaoning Educational committee (LZ2015067), the Natural Science Foundation of Liaoning Province (2015020 732), the Innovation Team Project of Liaoning Province (LT2015027), the Fund for Long-term Training of Young Teachers in Shenyang Pharmaceutical University (ZCJJ2013409) and the Program for Liaoning Excellent Talents in University (LR2015022). 


\section{Conflict of Interest}

The authors have no conflicts of interest.

\section{References}

[1] Palmer AM. Neuroprotective therapeutics for Alzheimer's disease: progress and prospects. Trends Pharmacol Sci 2011; 32: 141-147

[2] Tiraboschi P, Hansen LA, Thal L], Corey-Bloom J. The importance of neuritic plaques and tangles to the development and evolution of $\mathrm{AD}$. Neurology 2004; 62: 1984-1989

[3] Cho N, Choi JH, Yang H, Jeong EJ, Lee KY, Kim YC, Sung SH. Neuroprotective and anti-inflammatory effects of flavonoids isolated from Rhus verniciflua in neuronal HT22 and microglial BV2 cell lines. Food Chem Toxicol 2012; 50: 1940-1945

[4] Gibson GE, Zhang H. Abnormalities in oxidative processes in non-neuronal tissues from patients with Alzheimer's disease. J Alzheimers Dis 2001; 3: 329-338

[5] Gao HM, Hong JS. Why neurodegenerative diseases are progressive: uncontrolled inflammation drives disease progression. Trends Immunol 2008; 29: 357-365

[6] Heneka MT, O'Banion MK. Inflammatory processes in Alzheimer's disease. J Neuroimmunol 2007; 184: 69-91

[7] Xiang Z, Haroutunian V, Ho L, Purohit D, Pasinetti GM. Microglia activation in the brain as inflammatory biomarker of Alzheimer's disease neuropathology and clinical dementia. Dis Markers 2006; 22: 95-102

[8] Block ML, Hong JS. Microglia and inflammation-mediated neurodegeneration: Multiple triggers with a common mechanism. Prog Neurobiol 2005; 76: 77-98

[9] Li N, Ma Z], Li M], Xing YC, Hou Y. Natural potential therapeutic agents of neurodegenerative diseases from the traditional herbal medicine Chinese Dragon's Blood. J Ethnopharmacol 2014; 152: 508-521

[10] Li N, Zhang P, Wu HG, Wang J, Liu F, Wang WL. Natural flavonoids function as chemopreventive agents from Gancao (Glycyrrhiza inflata Batal). J Funct Foods 2015; 19: 563-574

[11] Hou Y, Li N, Xie GB, Wang J, Yuan Q, Jia CC, Liu X, Li GX, Tang YZ, Wang B. Pterostilbene exerts anti-neuroinflammatory effect on lipopolysaccharide-activated microglia via inhibition of MAPK signalling pathways. J Funct Foods 2015; 19: 676-687

[12] Li N, Meng DL, Pan Y, Cui QL, Li GX, Ni H, Sun Y, Qing DG, Jia XG, Pan YN, Hou Y. Anti-neuroinflammatory and NQO1 inducing activity of natural phytochemicals from Coreopsis tinctoria. J Funct Foods 2015; 17: 837846

[13] Afifi FU, Abu-Irmaileh B. Herbal medicine in Jordan with special emphasis on less commonly used medicinal herbs. J Ethnopharmacol 2000; 72: $101-110$

[14] Iranshahy M, Iranshahi M. Traditional uses, phytochemistry and pharmacology of asafoetida (Ferula assa-foetida oleo-gum-resin) - A review. J Ethnopharmacol 2011; 134: 1-10

[15] Motai T, Kitanaka S. Sesquiterpene phenylpropanoids from Ferula fukanensis and their nitric oxide production inhibitory effects. J Nat Prod 2005; 68: 365-368

[16] Kasaian J, Iranshahy M, Masullo M, Piacente S, Ebrahimi F, Iranshahi M. Sesquiterpene lactones from Ferula oopoda and their cytotoxic properties. J Asian Nat Prod Res 2014; 16: 248-253

[17] Motai T, Daikonya A, Kitanaka S. Sesquiterpene coumarins from Ferula fukanensis and their proinflammatory cytokine gene expression inhibitory effects. Chem Pharm Bull 2013; 61: 618-623

[18] Liu T, Osman K, Kaatz GW, Gibbons S, Mu Q. Antibacterial sesquiterpenoid derivatives from Ferula ferulaeoides. Planta Med 2013; 79: 701706
[19] Appendino G, Mercalli E, Fuzzati N, Arnoldi L, Stavri M, Gibbons S, Ballero M. Maxia A. Antimycobacterial coumarins from the Sardinian giant fennel (Ferula communis). J Nat Prod 2004; 67: 2108-2110

[20] Dastan D, Salehi P, Gohari AR, Zimmermann S, Kaiser M, Hamburger M, Khavasi HR, Ebrahimi SN. Disesquiterpene and sesquiterpene coumarins from Ferula pseudalliacea, and determination of their absolute configurations. Phytochemistry 2012; 78: 170-178

[21] Iranshahi M, Arfa P, Ramezani M, Jaafari MR, Sadeghian H, Bassarello C Piacente S, Pizza C. Sesquiterpene coumarins from Ferula szowitsiana and in vitro antileishmanial activity of 7-prenyloxycoumarins againpromastigotes. Phytochemistry 2007; 68: 554-561

[22] Kir'yanova I.A, Sklyar YE. Ferucrin isobutyrate and ferucrinone from Ferula foetidissima. Khim Prirod Soedinenii 1984; 5: 652-653

[23] Perel'son ME, Sheichenko VI, Sklyar YE, Andrianova VB. Configuration of kellerin and samarkandin. Pharm Chem J 1977; 11: 1050-1052

[24] Zaugg J, Ebrahimi SN, Smiesko M, Baburin I, Hering S, Hamburger M. Identification of GABA A receptor modulators in Kadsura longipedunculata and assignment of absolute configurations by quantum-chemical ECD calculations. Phytochemistry 2011; 72: 2385-2395

[25] Perel'son ME, Sklyar YE, Veselovskaya NV, Pimenov MG. Ferukrin - a new terpenoid coumarin from Ferula krylovii. Khim-Farm Zhur 1977; 11: 366369

[26] Hofer O, Widhalm M, Greger H. Circular dichroism of sesquiterpene-umbelliferone ethers and structure elucidation of a new derivative isolated from the gum resin “Asa Foetida”. Monatsh Chem 1984; 115: 1207-1218

[27] Iranshahi M, Amin G, Shafiee A. A new coumarin from Ferula persica. Pharm Biol 2004; 42: 440-442

[28] Marco JA, Sanz JF, Yuste A, Rustaiyan A. New Umbelliferone sesquiterpene ethers from roots of Ligularia persica. Liebigs Ann Chem 1991; 929-931

[29] Yang JR. Sesquiterpene coumarins of Ferula teterrima and Ferula sinkiangensis. Beijing: Chinese Academy of Medical Sciences \& Peking Union Medical College; 2006: 17-55

[30] Yang JR, jing S, Li ZH, Qin HL. [Chemical constituents from roots of Ferulc sinkiangensis]. China J Chin Materia Med 2007; 32: 2382-2384

[31] Appendino G, Tagliapietra S, Nano GM, Jakupovic J. Sesquiterpene coumarin ethers from asafetida. Phytochemistry 1994; 35: 183-186

[32] Abd El-Razek MH, Wu YC, Chang FR. Sesquiterpene coumarins from Ferula foetida. J Chin Chem Societ 2007; 54: 235-238

[33] Rosselli S, Maggio A, Bellone G, Formisano C, Basile A, Cicala C, Alfieri A Mascolo N, Bruno M. Antibacterial and anticoagulant activies of coumarins isolated from the flowers of Magydaris tomentosa. Planta Med 2007; 73: 116-120

[34] Frisch M], Trucks GW, Schlegel HB, Scuseria GE, Robb MA, Cheeseman JR, Scalmani G, Barone V, Mennucci B, Petersson GA, Nakatsuji H, Caricato M, Li X, Hratchian HP, Izmaylov AF, Bloino J, Zheng G, Sonnenberg JL, Hada M, Ehara M, Toyota K, Fukuda R, Hasegawa J, Ishida M, Nakajima T, Honda Y, Kitao O, Nakai H, Vreven T, Montgomery JA, Peralta JE, Ogliaro F, Bearpark M, Heyd IJ, Brothers E, Kudin KN, Staroverov VN, Kobayashi R, Normand J, Raghavachari K, Rendell A, Burant JC, lyengar SS, Tomasi J, Cossi M, Rega N, Millam JM, Klene M, Knox JE, Cross JB, Bakken V, Adamo C, Jaramillo J, Gomperts R, Stratmann RE, Yazyev O, Austin AJ, Cammi R, Pomelli C, Ochterski JW, Martin RL, Morokuma K, Zakrzewski VG, Voth GA, Salvador P, Dannenberg IJ, Dapprich S, Daniels AD, Farkas O, Foresman JB, Ortiz JV, Cioslowski J, Fox DJ. Gaussian 09, revision A02. Wallingford, CT: Gaussian, Inc; 2009

[35] O’Boyle NM, Tenderholt A, Langner KM. Cclib: a library for package independent computational chemistry algorithms. J Comput Chem 2009; 29: $839-845$

[36] Hou Y, Wu CF, Yang JY, He X, Bi XL, Yu L, Guo T. Effects of clozapine, olanzapine and haloperidol on nitric oxide production by lipopolysaccharide-activated N9 cells. Prog Neuropsychopharmacol Biol Psychiatry 2006; 30: 1523-1528 